\title{
A Review of In Situ Isotopic Studies of the Oklo and Bangombé Natural Fission Reactors Using Microbeam Analytical Techniques
}

\author{
Hiroshi Hidaka \\ Department of Earth and Planetary Sciences, Nagoya University, Chikusa-ku, Nagoya 464-8601, Japan; \\ hidaka@eps.nagoya-u.ac.jp; Tel.: +81-52-789-3829
}

Received: 30 September 2020; Accepted: 26 November 2020; Published: 27 November 2020

\begin{abstract}
Isotopic analyses of elements in the natural reactor materials have often been performed to understand the distribution behaviors of the fission products and to evaluate the function of nuclear reactions since the first discovery of a natural reactor in 1972. Several types of unique microminerals, including significant amounts of fission products, have been found in and around the Oklo and the Bangombé natural reactors. In the past two decades, microbeam techniques using ion and laser probe facilities have been effectively applied for the in situ isotopic analyses of individual microminerals to investigate the migration behaviors of fissiogenic radioisotopes produced in the reactors. This paper presents a review of interpretations of the isotopic results of microminerals found in and around the natural reactors.
\end{abstract}

Keywords: isotope; fission product; mass spectrometer

\section{Introduction}

The isotopic compositions of various elements in and around the Oklo and Bangombé natural reactors vary significantly because of the incorporation of fission products and the influence of nuclear reactions in the reactors. Isotopic analyses of the elements in the reactor materials provide useful information to understand the distribution behaviors of the fission products and to evaluate the function of nuclear reactions.

Before 2000, most isotopic studies were performed on bulk rock samples with chemical procedures. The samples were digested by acid and once turned to the solutions. Individual elements were then chemically separated for the isotopic analyses by thermal ionization mass spectrometry (TIMS) and/or inductively coupled plasma mass spectrometry (ICP-MS). In these conventional analyses, the results reveal the average information from the whole of the sample. However, the elements in the samples are heterogeneously distributed mainly in the individual minerals and/or specific microregions consisting of the samples. In the past two decades, in situ isotopic analyses using laser and ion probes have been widely applied in the geosciences research field. In situ isotopic instruments can analyze selected regions on a $\mu \mathrm{m}$ to $\mathrm{nm}$ scale, which is advantageous for analyses of fission products that are known to be heterogeneously distributed in uranium matrices. In fact, several kinds of microminerals consisting of fissiogenic isotopes were found in and around the natural reactors.

In this paper, I would like to review the isotopic results related to the Oklo and Bangombé reactors mainly based on my works using a sensitive high-resolution ion microprobe (SHRIMP) in the past two decades. The SHRIMP was originally designed at the Australian National University for the purpose of analyzing geological materials with a high spatial resolution and has been used particularly for in situ U-Pb analyses on individual zircon grains. As in other applications, the SHRIMP has been used for isotopic analyses of several elements of the natural reactor samples. My primary concern is 
to understand the long-term geochemical behaviors of fissiogenic isotopes produced in the reactors. Reactor samples generally consist of fissiogenic and nonfissiogenic components. The proportion of the two components can be identified from isotopic compositions of individual elements by mass spectrometric analyses. Variations in isotopic compositions resulting from the nuclear reactions can be used as tracers to understand the geochemical behavior of fission products in and around the reactors. Besides my work related to SHRIMP, two more topics, namely the use of a noble gas mass spectrometer with a laser probe and a secondary ion mass spectrometer (SIMS) combined with an accelerator mass spectrometer are covered in the latter part of this paper. Finally, I will introduce a unique isotopic approach to examine possible variations in fundamental constants, as one of the implications of the Oklo studies on particle physics.

The description of the samples treated in this paper and the related information are listed in Table 1.

Table 1. Descriptions of the samples used for in situ isotopic analyses.

\begin{tabular}{|c|c|c|c|c|c|}
\hline Reactor Zone & Location & Matrix & Minerals & Element & Reference \\
\hline Oklo RZ10 & D81-13 & in $\mathrm{RZ}$ & uraninite & $\mathrm{U}, \mathrm{Pb}, \mathrm{Nd}, \mathrm{Sm}, \mathrm{Gd}$ & [1] \\
\hline \multirow[t]{4}{*}{ Oklo RZ13 } & SD37 & in RZ & $\varepsilon$-particle & $\mathrm{U}, \mathrm{Zr}, \mathrm{Ru}, \mathrm{Mo}$ & [2] \\
\hline & SD37-10 & sandstone & illite, calcite, quartz & $\mathrm{U}, \mathrm{Pb}, \mathrm{Ba}$ & [3] \\
\hline & SD37- & in $\mathrm{RZ}$ & uraninite, phosphate & $\mathrm{Kr}, \mathrm{Xe}$ & {$[4,5]$} \\
\hline & SD37- & in RZ & uraninite & $\mathrm{Ba}, \mathrm{Cs}, \mathrm{Eu}$ & {$[6]$} \\
\hline \multirow[t]{7}{*}{ Bangombé } & BAX03-1040 & black shales & uraninite & $\mathrm{U}, \mathrm{Pb}, \mathrm{Ce}, \mathrm{Nd}, \mathrm{Sm}, \mathrm{Eu}$ & [7] \\
\hline & BAX03-1065 & black shales & uraninite & $\mathrm{U}, \mathrm{Pb}, \mathrm{Ce}, \mathrm{Nd}, \mathrm{Sm}, \mathrm{Eu}$ & [7] \\
\hline & BAX03-1170 & clay & coffinite, zircon, galena & $\mathrm{U}, \mathrm{Pb}, \mathrm{Ce}, \mathrm{Nd}, \mathrm{Sm}, \mathrm{Eu}$ & [8] \\
\hline & BAX03-1215 & sandstone & uraninite & $\mathrm{U}, \mathrm{Pb}$ & [9] \\
\hline & BAX03-1225 & sandstone & coffinite, françoisite & $\mathrm{U}, \mathrm{Pb}, \mathrm{Ce}, \mathrm{Nd}, \mathrm{Sm}, \mathrm{Eu}$ & [9] \\
\hline & BAХ03-1240 & sandstone & coffinite & $\mathrm{U}, \mathrm{Pb}, \mathrm{Ce}, \mathrm{Nd}, \mathrm{Sm}$ & [9] \\
\hline & BAХ03-1290 & sandstone & uraninite, goethite & $\mathrm{U}, \mathrm{Pb}, \mathrm{Ce}, \mathrm{Nd}, \mathrm{Sm}$ & [9] \\
\hline
\end{tabular}

\section{SHRIMP Analyses}

\subsection{Selective Uptake of ${ }^{226} \mathrm{Ra}$ in Clay Minerals Deduced from ${ }^{206} \mathrm{~Pb}$ Isotopic Excess}

Radium has no stable isotopes. Radium-226, having the longest half-life $\left(t_{1 / 2}=1600\right.$ years $)$ among radium isotopes, exists as a precursor of decay product from ${ }^{238} \mathrm{U}$ in nature and ultimately decays to ${ }^{206} \mathrm{~Pb}$. It is of particular interest to recognize the environmental behavior of $\mathrm{Ra}$ from the viewpoint of the long-term safety of radioactive waste disposal. However, experimental approaches of Ra behavior in the natural environment has proven difficult due to its high radioactivity, and Ra is difficult to analyze by direct detection because of its extremely low level in nature. Isotopic evidence of Ra transportation and its selective uptake into clay minerals was found indirectly from $\mathrm{Pb}$ isotopic analyses of the clays in and around the Oklo reactor zone (RZ) [3].

In a sandstone layer at underground drift SD37 close to RZ13, there are numerous calcite veins. It is considered that the calcite veins were formed in association with the hydrothermal effect related to a dolerite dyke intrusion that occurred $860 \mathrm{Ma}$ ago about $15 \mathrm{~m}$ from RZ13. The sample collected from the sandstone layer at drift SD37 contains small illite grains (a few tens to $100 \mu \mathrm{m}$ in size) found in fine calcite veins with a width of $0.1-0.2 \mathrm{~mm}$ in the quartz matrix (Figure 1). As the result of the systematic $\mathrm{Pb}$ isotopic study of this sample, the data on calcite and quartz coexisting with illite indicate the formation age of each component, $2.15 \mathrm{Ga}$ and $0.88 \mathrm{Ga}$, respectively, while those of illite do not. It is worth noting that most $\mathrm{Pb}$ isotopic ratios in the illite grains show ${ }^{207} \mathrm{~Pb} /{ }^{206} \mathrm{~Pb}<0.04604$, which is less than a lower limit of natural radiogenic $\mathrm{Pb}$ isotopic ratio decayed from the secular equilibrium in the ${ }^{235} \mathrm{U}$ - and ${ }^{238} \mathrm{U}$-decay systems. 


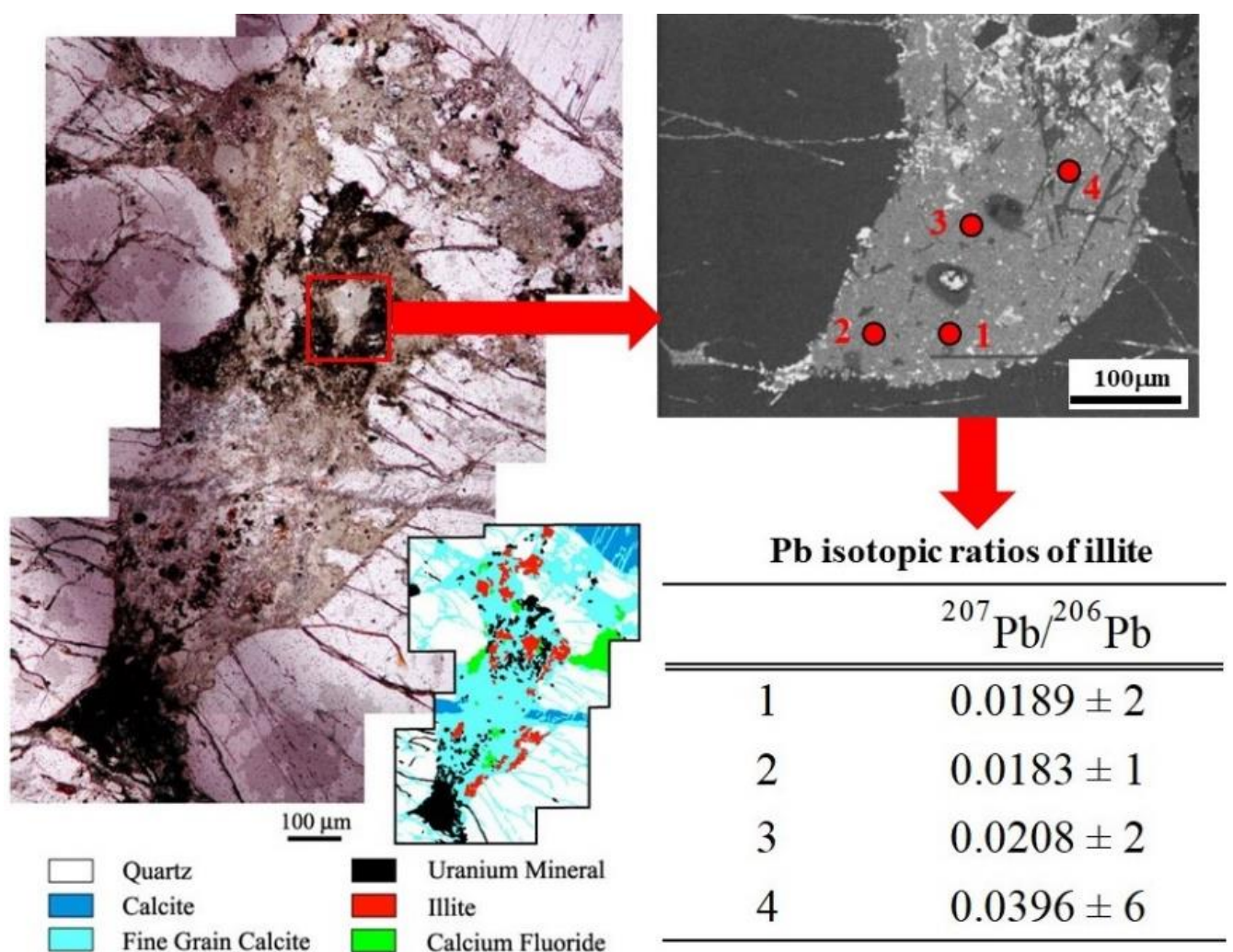

Figure 1. The situation and location of illite grains used for the in situ $\mathrm{Pb}$ isotopic analyses by sensitive high-resolution ion microprobe (SHRIMP). Optical micrograph and mineral composition mapping of thin section of the sample from the sandstone layer at the drift SD37 at the Oklo RZ13 (left), and SEM image of one of illite grains and analytical spots (red circles) for Pb isotopic measurements by SHRIMP (upper right). The result of $\mathrm{Pb}$ isotopic ratios given by the SHRIMP analyses are listed in the table (lower right).

Two possible explanations are considered to produce the extremely low ${ }^{207} \mathrm{~Pb} /{ }^{206} \mathrm{~Pb}$ isotopic ratios in the illite grains: (1) Pb decayed from depleted $\mathrm{U}$, or (2) enrichment of ${ }^{206} \mathrm{~Pb}$ in the natural system surrounding RZ13. Depleted U can indeed produce lower ${ }^{207} \mathrm{~Pb} /{ }^{206} \mathrm{~Pb}$, however, an extremely high depletion of ${ }^{235} \mathrm{U}\left({ }^{235} \mathrm{U} /{ }^{238} \mathrm{U}<0.00096\right)$ is necessary to produce low ${ }^{207} \mathrm{~Pb} /{ }^{206} \mathrm{~Pb}$ such as 0.0183 observed in the illite. Such a high depletion of ${ }^{235} \mathrm{U}$ has not been reported even in the RZs. Uranium isotopic compositions in the illite show normal values $\left({ }^{235} \mathrm{U} /{ }^{238} \mathrm{U}=0.00725\right)$ without depletion of ${ }^{235} \mathrm{U}$.

It is reasonable to consider that the enrichment of ${ }^{206} \mathrm{~Pb}$ results in low ${ }^{207} \mathrm{~Pb} /{ }^{206} \mathrm{~Pb}$ ratios from the selective uptake of ${ }^{226} \mathrm{Ra}$ on the illite grains. The selective uptake of Ra on clay minerals such as bentonite, kaolinite, illite and montmorillonite has been reported in experimental sorption studies [10,11]. In most studies on the geochemical behavior of $\mathrm{Ra}$, Ba has been often used as a chemical tracer of ${ }^{226} \mathrm{Ra}$ because of the chemical similarities between $\mathrm{Ba}$ and $\mathrm{Ra}[12,13]$. The illite grains from SD37 contain a greater abundance of $\mathrm{Ba}$ (up to $\sim 5000 \mathrm{ppm}$ ) than other peripheral minerals such as calcite $(0.006 \sim 0.13 \mathrm{ppm})$ and quartz (0.025 0.26 ppm). Figure 2 shows a diagram between $\mathrm{Ba}$ elemental abundances and $\mathrm{Pb}$ isotopic ratios in the illite, calcite and quartz of the sample from one of drifts, SD37, closely located at RZ13. The data points of illite with high Ba contents and low ${ }^{207} \mathrm{~Pb} /{ }^{206} \mathrm{~Pb}$ isotopic ratios are fairly isolated from the other data points of quartz and calcite in the figure. The following scenario is reasonable to produce abnormally low ${ }^{207} \mathrm{~Pb} /{ }^{206} \mathrm{~Pb}$ isotopic ratios in the illite: (1) $\mathrm{CO}_{2}$-rich groundwater fills veins in the basement rocks near the U-deposit; (2) Ra leaches from a chemically weathered U-deposit, and as $\mathrm{Ra}$ carbonate is soluble, $\mathrm{Ra}$ dissolves and is carried away by $\mathrm{CO}_{2}$-rich groundwater; (3) Ra (and $\mathrm{Ba}$ ) is selectively adsorbed on illite grains migrated in the veins; (4) Adsorbed ${ }^{226} \mathrm{Ra}$ decays to ${ }^{206} \mathrm{~Pb}$, resulting in low ${ }^{207} \mathrm{~Pb} /{ }^{206} \mathrm{~Pb}$ isotopic ratios due to the enrichment of ${ }^{206} \mathrm{~Pb}$ [3]. 


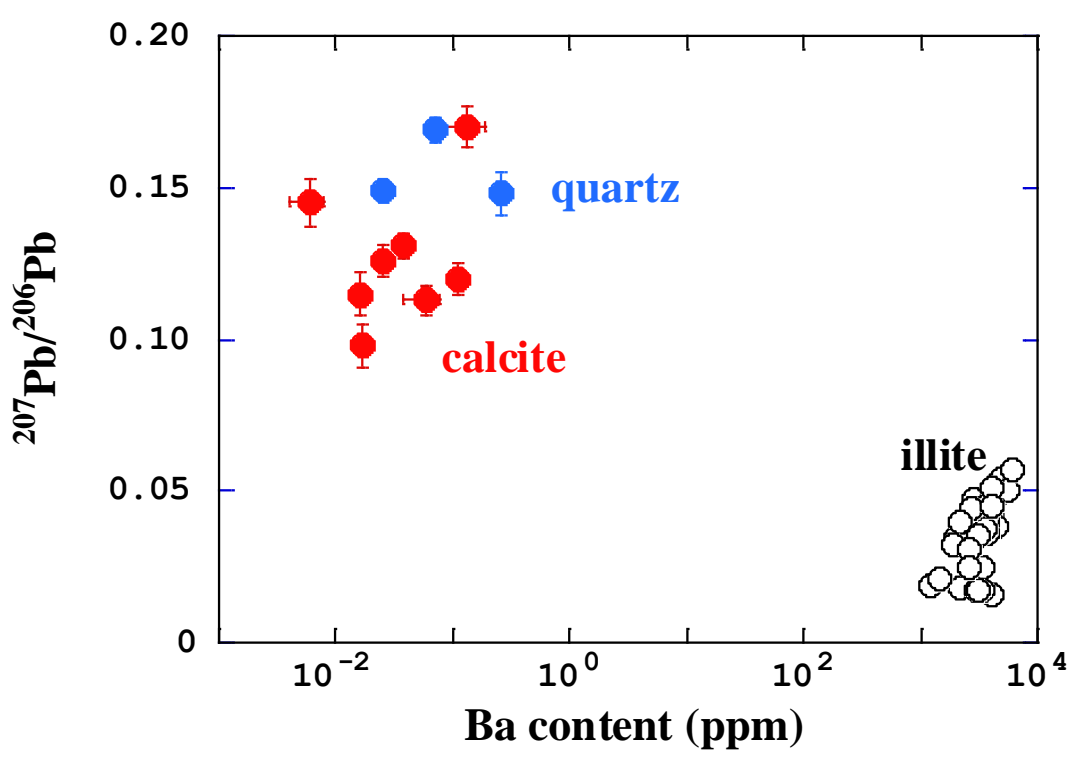

Figure 2. A diagram between $\mathrm{Ba}$ elemental abundances and ${ }^{207} \mathrm{~Pb} /{ }^{206} \mathrm{~Pb}$ isotopic ratios in individual analytical points of illite (white), quartz (blue) and calcite (red). The data are from [3].

\subsection{Migration Behavior of ${ }^{239} \mathrm{Pu}$ Evaluated from the Isotopic Variations of ${ }^{235} \mathrm{U}$}

Several types of actinide isotopes were produced by nuclear reactions in the Oklo RZs. The major actinide isotopes produced in the reactors are ${ }^{236} \mathrm{U},{ }^{237} \mathrm{~Np}$, and ${ }^{239} \mathrm{Pu}$, and they ultimately decayed to ${ }^{232} \mathrm{Th},{ }^{209} \mathrm{Bi}$ and ${ }^{235} \mathrm{U}$, respectively. ${ }^{235} \mathrm{U}$ depletion $\left({ }^{235} \mathrm{U} /{ }^{238} \mathrm{U}<0.00725\right)$ has been generally found in the Oklo RZ samples, because the fission of ${ }^{235} \mathrm{U}$ was main reaction. Uranium-235-depleted U migrated from the reactor to peripheral rocks associated with dissolution of reactor $U$, to produce isotopic anomalies in the wall rocks of the reactor itself. However, as a very rare case, isotopic enrichment of ${ }^{235} \mathrm{U}\left({ }^{235} \mathrm{U} /{ }^{238} \mathrm{U}>0.00725\right)$ was found and interpreted as a result of selective uptake of ${ }^{239} \mathrm{Pu}$ in association with chemical differentiation between $\mathrm{U}$ and $\mathrm{Pu}$. The production of ${ }^{239} \mathrm{Pu}$ occurs by the neutron capture reaction of ${ }^{238} \mathrm{U}\left(\mathrm{n}, \gamma 2 \beta^{-}\right){ }^{239} \mathrm{Pu}$ in the reactors. Then, ${ }^{239} \mathrm{Pu}$ decays with a half-life of $2.4 \times 10^{4}$ years, to ${ }^{235} \mathrm{U}$. Uranium-235 isotopic enrichments have been observed in clay minerals found in the surrounding rock of the Oklo reactors [14] and in apatite [1,15].

Early investigations of the Oklo reactors (RZs1-6) lead to the conclusion that Pu has not migrated out of the reactors [16]. However, as a result of in situ U isotopic analyses by SHRIMP, as shown in Figure 3, apatite grain from the boundary between RZ10 and the sandstone layer showed significantly large ${ }^{235} \mathrm{U}$ excess up to ${ }^{235} \mathrm{U} /{ }^{238} \mathrm{U}=0.01707$ [1], although uraninites surrounding the apatite showed depleted ${ }^{235} \mathrm{U}\left({ }^{235} \mathrm{U} /{ }^{238} \mathrm{U}=0.0066\right)$. It seems reasonable that $\mathrm{Pu}$ was trapped into the apatite grain, because the apatite includes a large amount of LREE. LREE and especially $\mathrm{Nd}$ are often used as a geochemical analogue of $\mathrm{Pu}[17,18]$. Considering that a large amount of $\mathrm{Nd}$ is included in the apatite grain, it seems reasonable that $\mathrm{Pu}$ was trapped in the apatite grain. Plutonium might be present as trivalent from under reducing conditions and behaved with other trivalent species such as $\mathrm{Nd}$.

\subsection{Evidence for Water Radiolysis in the Natural Reactors}

Spent fuel in contact with water undergoes oxidative dissolution under both oxidizing and reducing environments through the formation of water radiolysis products, $\mathrm{OH}^{*}$ and $\mathrm{H}_{2} \mathrm{O}_{2}$ [19]. Interestingly, geochemical evidence of water radiolysis can be seen in the natural products of the Oklo RZs. 

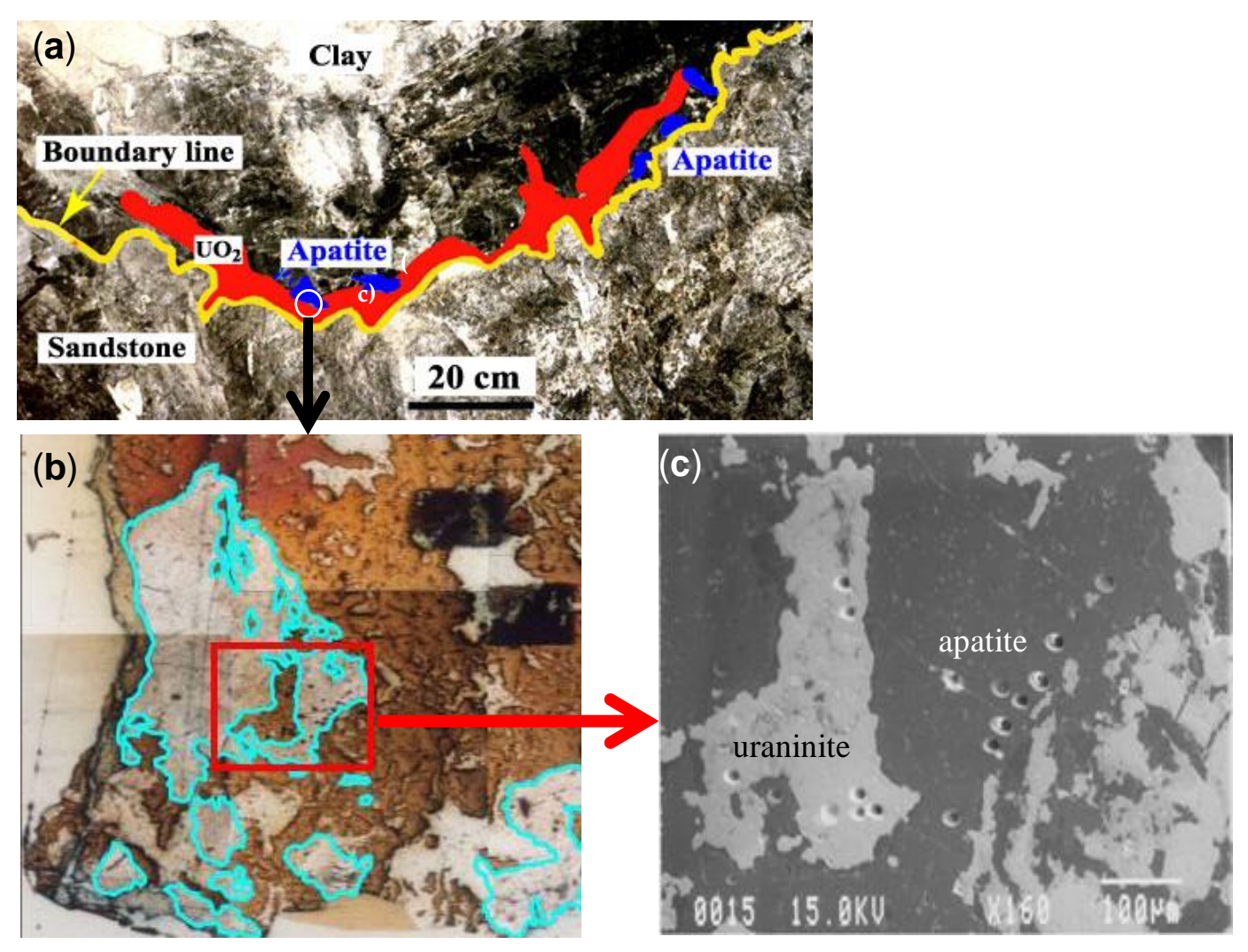

Figure 3. The situation and location of apatite used for the in situ U isotopic analyses by SHRIMP. (a) The sample including apatite grains (blue) and a gangue of uraninite (red) taken from one of drifts, D81, around the boundary between sandstone and clay layers close to RZ 10. (b) Optical micrograph of thin section of a part of the sample from (a). (c) Back-scattered-electron (BSE) image of a part of the thin section sample (b). 10 to $20 \mu \mathrm{m}$-sized craters in the photo (c) are in situ analytical spots by SHRIMP.

The major $\mathrm{Pb}$ minerals found in the natural reactors are galena (PbS). 20-30 $\mu \mathrm{m}$-sized galena grains are often observed in the uraninite matrices of all over the reactors. Besides the galena grains, very rare lead oxide minerals, minium $\left(\mathrm{Pb}_{3} \mathrm{O}_{4}\right)$, are found in a chlorite matrix and in an apatite crystal at the boundary region of RZ10 [1,20]. Highly oxidizing conditions are necessary for the formation of minium. However, such oxidizing conditions are generally not expected in natural reactors where reducing conditions have prevailed. Redox conditions of the formation of $\mathrm{Pb}$ minerals are restricted to low oxygen fugacity $\left(f \mathrm{O}_{2}\right)$ for $\mathrm{PbS}$, and high $f \mathrm{O}_{2}$ for $\mathrm{Pb}_{3} \mathrm{O}_{4}$. Radiolysis of water is the only means of producing the locally oxidizing conditions in natural reactors. Radiolysis of water is commonly observed when the spent fuel is exposed to groundwater; oxidants $\left(\mathrm{OH}^{*}, \mathrm{H}_{2} \mathrm{O}_{2}, \mathrm{HO}_{2}{ }^{*}\right.$ and $\left.\mathrm{O}_{2}\right)$ and reductants (hydrated electrons, $\mathrm{H}^{*}$ and $\mathrm{H}_{2}$ ) are then produced in the spent fuel. The oxidants from radiolysis of water may have been stored and played a role in locally changing the oxidizing conditions in the natural reactors.

Isotopic analyses showed that nearly all $\mathrm{Pb}$ isotopes of galena and minium grains are radiogenic with very low common $\mathrm{Pb}$ abundances $\left({ }^{204} \mathrm{~Pb} /{ }^{206} \mathrm{~Pb}<0.00012\right.$ for galena, and $<0.00007$ for minium). Figure 4 shows a ${ }^{204} \mathrm{~Pb} /{ }^{206} \mathrm{~Pb}$ vs. ${ }^{207} \mathrm{~Pb} /{ }^{206} \mathrm{~Pb}$ diagram of galena and minium in a uraninite of $\mathrm{RZ} 10$. The data points of galena and minium are plotted on the same single line, suggesting that the minium was formed by later dissolution of the galena. 


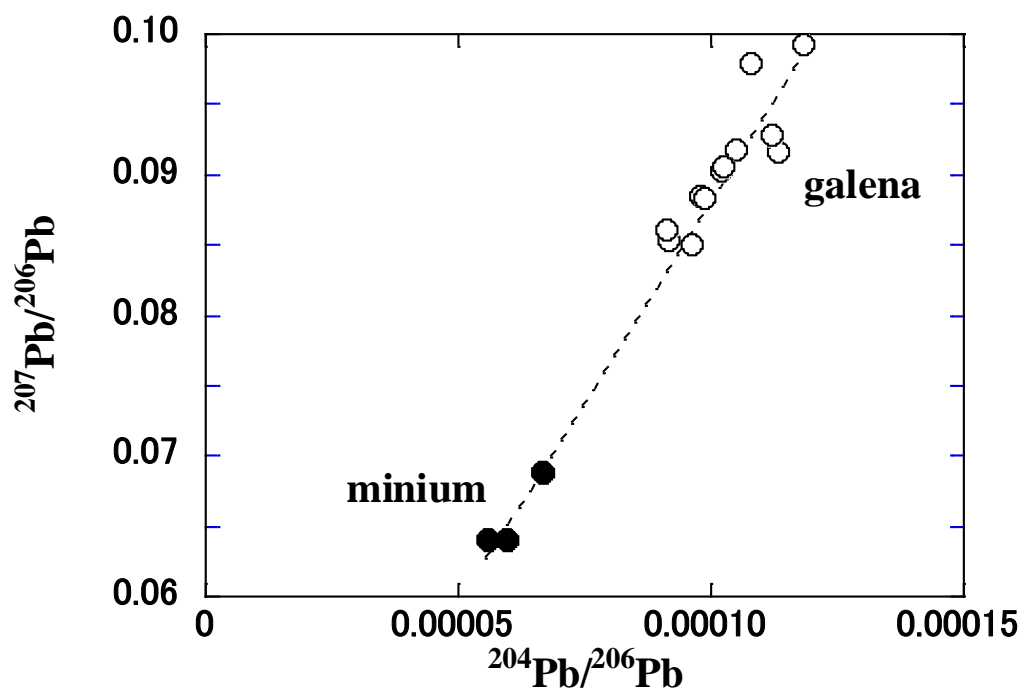

Figure 4. A diagram between ${ }^{204} \mathrm{~Pb} /{ }^{206} \mathrm{~Pb}$ and ${ }^{207} \mathrm{~Pb} /{ }^{206} \mathrm{~Pb}$ isotopic ratios of galena (open circles) and minium grains (closed circles) found in the sample D81-13 at RZ10. The data sets of galena and minium are plotted on the same single line. The data are from [1].

\subsection{Isotopic Variations of Fissiogenic Mo, $\mathrm{Zr}$, and $\mathrm{Ru}$ in $\varepsilon$-Particles}

Tiny alloy particles consisting of fissiogenic $\mathrm{Mo}, \mathrm{Tc}, \mathrm{Ru}, \mathrm{Rh}, \mathrm{Pd}, \mathrm{Ag}, \mathrm{Cd}, \mathrm{In}, \mathrm{Sn}, \mathrm{Sb}$ and Te, which are referred to as $\varepsilon$-particles, are formed in spent nuclear fuels [21]. The electron microscopic observation shows that the $\varepsilon$-particles are localized in the grain boundary regions and/or in the fuel-clad gap [22]. The chemical compositions of the $\varepsilon$-particles extracted from spent fuel vary in a narrow range and the averages for the chemical composition (wt. \%) are $32.7 \% \mathrm{Mo}, 40.5 \% \mathrm{Ru}, 7 \% \mathrm{Tc}, 4.2 \% \mathrm{Rh}, 11.7 \% \mathrm{Pd}$ and 3.8\% Te [23]. Finding the similar particles in RZs10 and 13 of the Oklo uranium deposit [24-27] and in sandstone below the Bangombé RZ [28] have been reported. The particles consist of several fine minerals intergrown with galena $(\mathrm{PbS})$ and U-rich minerals [24]. The sizes of the aggregates are generally small in the range from a few $\mu \mathrm{m}$ to $100 \mu \mathrm{m}$. Larger-sized particles with diameters of $\sim 100 \mu \mathrm{m}$, as shown in Figure 5, were found particularly in the sample SD37-S2/CD collected from RZ13.

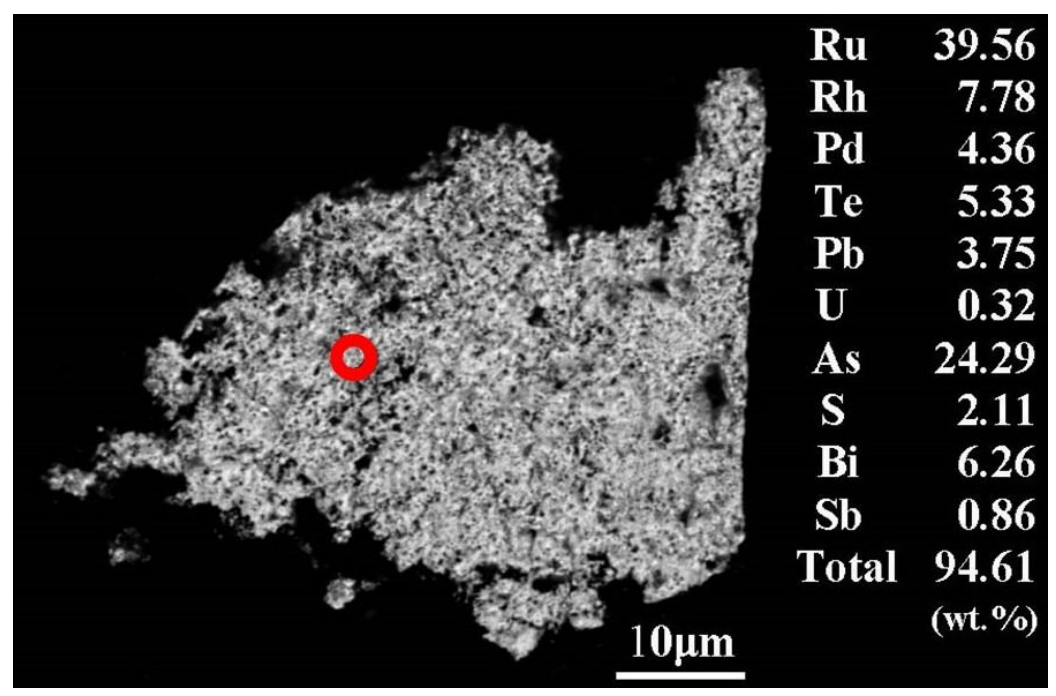

Figure 5. A back-scattered-electron (BSE) image of a large size of $\varepsilon$-particle in epoxy resin disc. The particle was found in the reactor sample from SD37-S2/CD at RZ13. The red circle in the photo is an analytical spot for the determination of the chemical composition by electron probe microanalyzer (EPMA). The result of the EPMA analysis is listed in the right column. 
Because many elements in the Oklo reactors show the isotopic variations due to fission and neutron capture reactions, isotopic results from the reactor materials may provide practical information on the long-term behavior of fission products in the samples. Isotopic analyses in microscopic regions by secondary ion mass spectrometry (SIMS) make it possible to understand the migration and retardation processes of fission products in individual minerals. In particular, a large variation in the ${ }^{99} \mathrm{Ru} /{ }^{101} \mathrm{Ru}$ isotopic ratios was observed in the $\varepsilon$-particles, while other isotopic ratios such as ${ }^{90} \mathrm{Zr} /{ }^{91} \mathrm{Zr}$ and ${ }^{95} \mathrm{Mo} /{ }^{97} \mathrm{Mo}$ were nearly constant in the particles [2]. The data suggest that the $\varepsilon$-particles formed under various redox conditions. The $\mathrm{Zr}$ and Mo isotopic ratios, ${ }^{90} \mathrm{Zr} /{ }^{91} \mathrm{Zr}=1.7-2.1$ and ${ }^{95} \mathrm{Mo} /{ }^{97} \mathrm{Mo}=0.82-0.93$, for most particles showed little variations, which can be simply explained by a two-component mixing between fissiogenic and nonfissiogenic materials. On the other hand, a large variation in the ${ }^{99} \mathrm{Ru} /{ }^{101} \mathrm{Ru}$ ratios from 0.32 to 1.7 cannot be explained only by the mixing of fissiogenic and nonfissiogenic components. The data suggest that chemical fractionation occurred between $\mathrm{Tc}$ and $\mathrm{Ru}$ under various redox conditions due to the radiolysis of water before decay of ${ }^{99} \mathrm{Tc}$ with a half-life of $2.1 \times 10^{5}$ years to ${ }^{99} \mathrm{Ru}$. In addition, a large variation of ${ }^{235} \mathrm{U} /{ }^{238} \mathrm{U}$ in the range from 0.00478 to 0.01466 was also found in the same particles [2]. In the case of $U$ isotopic compositions, depletion of ${ }^{235} \mathrm{U}$ is generally observed in the reactor materials because of the consumption of ${ }^{235} \mathrm{U}$ by fission. In particular, isotopic excess of ${ }^{235} \mathrm{U}$ can be explained by the enrichment of ${ }^{239} \mathrm{Pu}$ after chemical fractionation between $\mathrm{Pu}$ and $\mathrm{U}$ in local oxidizing conditions made possible by radiolytic oxygen [1]. The large variations in ${ }^{99} \mathrm{Ru} /{ }^{101} \mathrm{Ru}$ and ${ }^{235} \mathrm{U} /{ }^{238} \mathrm{U}$ isotopic ratios suggest the implication of water radiolysis for the formation of $\varepsilon$-particles under various redox conditions.

\subsection{Fissiogenic REE in Phosphate, Uraninite and Zircon}

It is of great interest to study the behavior of rare earth elements (REE) in the geosphere, because a part of REE ( $\mathrm{La}, \mathrm{Ce}, \mathrm{Nd}$ ) possesses high fission production yields and their distribution behavior is closely related to general geochemical events. Therefore, it is important to decipher the geochemical behavior of fissiogenic REE in RZs in response to nuclear reactions and postreactor weathering processes.

As the result of the isotopic analyses of $\mathrm{U}$ and REE, $\mathrm{U}$ - and REE-bearing secondary minerals such as coffinite $\left(\mathrm{USiO}_{4}\right)$, florencite ((REE) $\left.\mathrm{Al}_{3}\left(\mathrm{PO}_{4}\right)_{2}(\mathrm{OH})_{6}\right)$, and françoisite $\left((\mathrm{REE})\left(\mathrm{UO}_{2}\right)_{3} \mathrm{O}(\mathrm{OH})\left(\mathrm{PO}_{4}\right) 6 \mathrm{H}_{2} \mathrm{O}\right)$ found in a sandstone layer $30-110 \mathrm{~cm}$ beneath the Bangombé $\mathrm{RZ}$ contain depleted $\mathrm{U}$ and a large amount of fissiogenic lighter REE, such as $\mathrm{Ce}, \mathrm{Nd}$, and $\mathrm{Eu}$ [9]. Interestingly, the proportion of fissiogenic and nonfissiogenic REE components in the minerals varied based on distance from the RZ. Figure 6 shows a chemical fractionation of individual REE in the secondary minerals based on a two-component mixing model. In the underlayer (sandstone) of the reactor, the proportion of the fissiogenic component for individual elements gradually decreases the greater the distance from the reactor. On the other hand, in the clay layers just above the reactor, the isotopic ratios of individual elements are widely variable between the fissiogenic and nonfissiogenic lines. In addition, most isotopic data in the black shales above the clay layer are close to those of nonfissiogenic materials. These isotopic results in Figure 6 show that clay plays a role as a barrier to trap most fissiogenic REE and to prevent their migration. Furthermore, the chemical differentiation factor of Ce clearly differs from those of other REE, which suggests the occurrence of large fractionation between Ce and other REE during the formation of the secondary minerals under an oxidizing atmosphere. 

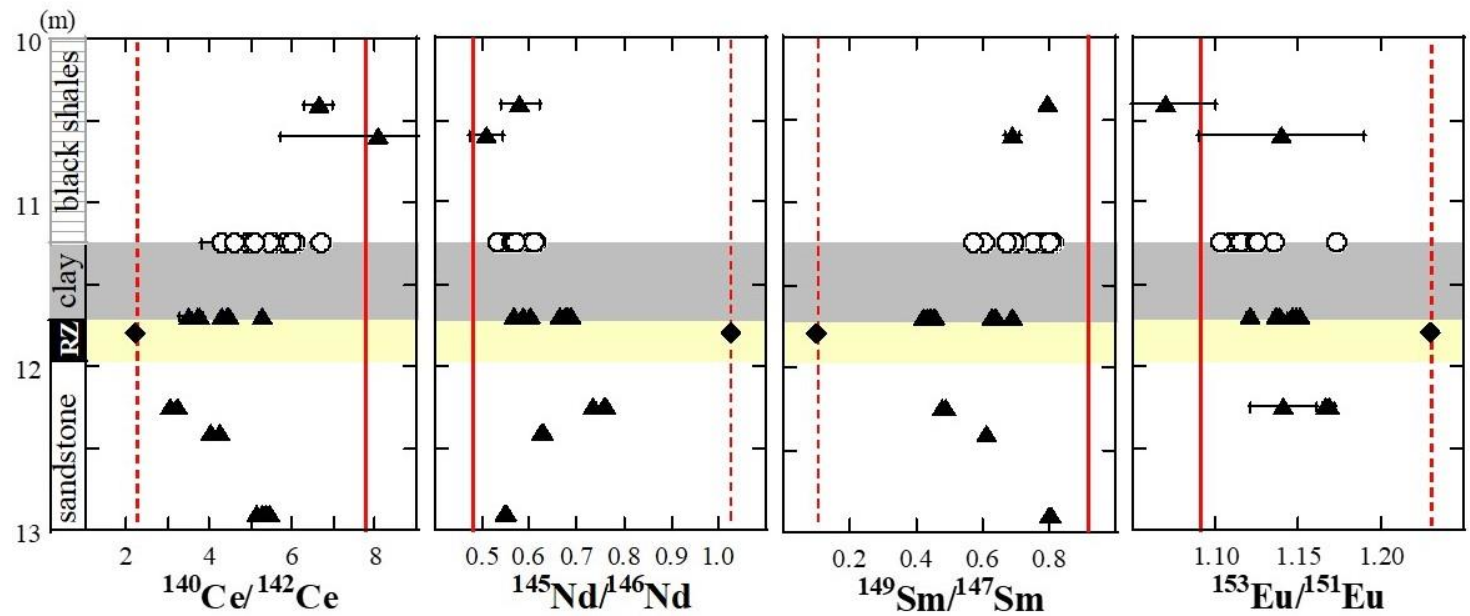

Figure 6. Isotopic variations of ${ }^{140} \mathrm{Ce} /{ }^{142} \mathrm{Ce},{ }^{145} \mathrm{Nd} /{ }^{146} \mathrm{Nd},{ }^{149} \mathrm{Sm} /{ }^{147} \mathrm{Sm}$, and ${ }^{151} \mathrm{Eu} /{ }^{153} \mathrm{Eu}$ of uraninite (closed diamond) in the Bangombé natural reactor and of zircons (open circles) and U-bearing minerals (closed triangles) in the sandstones, clays and black shales as the surrounding layers over and under the reactor. The samples were collected from one of bore-holes, BAX03 at Bangombé region. The numbers of the vertical axis indicate the depths from the ground surface in the unit of meter. The yellow and gray zones in the figure show the core of reactor and clay layer. The dotted red lines and solid red lines in the individual four columns in the figure show the isotopic ratios of fissiogenic and nonfissiogenic materials for ${ }^{140} \mathrm{Ce} /{ }^{142} \mathrm{Ce}(\mathrm{left}),{ }^{145} \mathrm{Nd} /{ }^{146} \mathrm{Nd},{ }^{149} \mathrm{Sm} /{ }^{147} \mathrm{Sm}$, and ${ }^{151} \mathrm{Eu} /{ }^{153} \mathrm{Eu}$ (right), respectively. The proportions of fissiogenic components in the individual minerals decrease with the distances from the reactor zone in the sandstone and black shales. The data are from $[9,29,30]$.

The two-component mixing model between the 2.05 Ga-old original uraninite and fissiogenic material from the reactor component was also supported by the $\mathrm{Pb}$ isotopic data. Furthermore, the $\mathrm{Pb}$ isotopic data can put the temporal constraint into the timing of the large mobilization of $\mathrm{U}, \mathrm{Pb}$ and fissiogenic REE from the reactor of around $0.8 \mathrm{Ga}$ corresponding to the age of dolerite dyke intrusion into the Oklo uranium deposit and the formation of the secondary minerals consisting of the mixture of $2.05 \mathrm{Ga}$-old original minerals and reactor materials by recent alteration [9].

Zircon is one of accessary minerals which are suitable for $\mathrm{U}-\mathrm{Pb}$ chronometrical application, because it contains a certain amount of $\mathrm{U}$ and less initial $\mathrm{Pb}$. Uranium-lead analysis of zircon using SHRIMP was progressively accepted by the Earth science community, and a wealth of chronological data by SHRIMP has been published since the mid-1980s. To discuss the thermal history of the Oklo and Bangombé areas, U-Pb systematics of zircon are very informative [29,30].

Forty-eight zircon grains from the clay and black shale layers $10 \mathrm{~cm}$ and $50 \mathrm{~cm}$ above the Bangombé reactor were collected for $\mathrm{REE}, \mathrm{U}$ and $\mathrm{Pb}$ isotopic measurements $[7,8]$. As a result of mineral observation by back-scattered electron images and Raman spectroscopy, the zircons showed highly altered and low crystallinity. The $U$ contents of the analyzed zircons varied widely from $<0.01$ to $2.83 \times 10^{5} \mathrm{ppm}$ [8]. Some zircon grains contained a certain amount of fissiogenic REE. The U-Pb system was largely disturbed by mobilization and chemical fractionation of $\mathrm{U}$ and $\mathrm{Pb}$ in association with recent alteration.

\section{Fissiogenic Noble Gases in Phosphates}

A La-Ce-Sr-Ca aluminous hydroxy phosphate (hereafter, Al-phosphate) found in the SD37 gallery on the east face of RZ13 consists of large amounts of fissiogenic LREE ( $\mathrm{La}, \mathrm{Ce}$ and Nd) and nonfissiogenic Sr [31]. Later, Meshik et al. [4,5] found that the Al-phosphate contains significant amounts of anomalous Xe isotopes including fissiogenic Xe. The concentrations of fissiogenic Xe in the Al-phosphates are considerably higher than those in U-oxides as matrices. This suggests that large amounts of fissiogenic gases were lost from U-oxides and recaptured by Al-phosphates. Interestingly, as shown in Figure 7, the Al-phosphates contain excess ${ }^{130} \mathrm{Xe}$ which correlates with ${ }^{129} \mathrm{Xe}$ abundances. ${ }^{130} \mathrm{Xe}$ is not produced 
by fission, because it is shielded by ${ }^{130} \mathrm{Te}$ in the fission chain. Alternatively, ${ }^{130} \mathrm{Xe}$ is produced by the reaction of ${ }^{129} \mathrm{I}(\mathrm{n}, \gamma \beta-)^{130} \mathrm{Xe}$. This is thus isotopic evidence for the migration of fissiogenic ${ }^{129} \mathrm{I}$ from the RZ uraninite into the Al-phosphates.

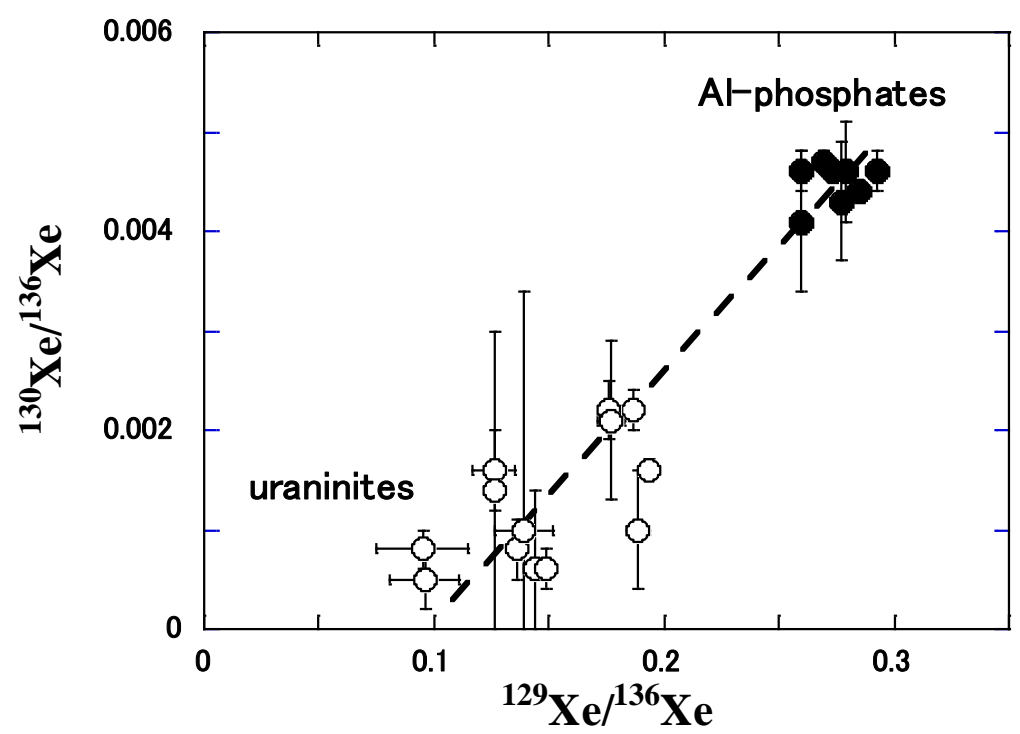

Figure 7. A diagram of $\mathrm{Xe}$ isotopic ratios between ${ }^{129} \mathrm{Xe} /{ }^{136} \mathrm{Xe}$ and ${ }^{130} \mathrm{Xe} /{ }^{136} \mathrm{Xe}$ from uraninites and Al-phosphates in the sample from SD37 (RZ13). The data are from [4].

Isotopic deficits of ${ }^{136} \mathrm{Xe}$ are the most remarkable property of the Al-phosphates' Xe isotopic compositions. Iodine-136 is the radioactive precursor to ${ }^{136} \mathrm{Xe}$ and has a very short half-life (86 s), therefore fissiogenic ${ }^{136}$ Xe has a greater chance of being lost before other fissiogenic Xe isotopes start to accumulate. This specific isotopic composition of $\mathrm{Xe}$ in the Al-phosphates defines a record of cycling operation for the reactor with 30-min active pulses separated by 2.5-h dormant periods [5].

\section{Fissiogenic Cs Behavior from Ba Isotopic Study}

Since Cs is highly produced by the fission reaction of ${ }^{235} \mathrm{U}$, it is important to understand the long-term behavior of Cs in environments for the disposal of radioactive waste. Because Cs ( $\left.{ }^{133} \mathrm{Cs}\right)$ is a monoisotopic element, fissiogenic and nonfissiogenic ${ }^{133} \mathrm{Cs}$ cannot be directly distinguished by mass spectrometric techniques. However, isotopic abundance patterns of fissiogenic Ba in the RZs can be used as a useful indicator to understand the geochemical behavior of long-lived ${ }^{135} \mathrm{Cs}\left(\mathrm{t}_{1 / 2}=2.3 \times 10^{6}\right.$ years $)$ and ${ }^{137} \mathrm{Cs}\left(\mathrm{t}_{1 / 2}=30\right.$ years $)$, which ultimately decay to ${ }^{135} \mathrm{Ba}$ and ${ }^{137} \mathrm{Ba}$, respectively.

Barium has seven stable isotopes with the mass numbers 130, 132, 134, 135, 136, 137 and 138. Three of the seven isotopes, ${ }^{135} \mathrm{Ba},{ }^{137} \mathrm{Ba}$ and ${ }^{138} \mathrm{Ba}$, are fissiogenic, while the other four isotopes, ${ }^{130} \mathrm{Ba}$, ${ }^{132} \mathrm{Ba},{ }^{134} \mathrm{Ba}$ and ${ }^{137} \mathrm{Ba}$, are nonfissiogenic. As the results of previous $\mathrm{Ba}$ isotopic studies, long-lived fissiogenic $\mathrm{C}$ s isotopes as well as $\mathrm{Rb}, \mathrm{Sr}$, and $\mathrm{Ba}$ are known to have been nearly removed from the reactors because of their incompatibilities with the uranium matrix materials and their high solubility and reactivity [32-34]. It is calculated that the majority of fissiogenic Cs (>90\%) was removed even in less-weathered RZs [34]. Where most of the fissiogenic Cs has gone is a major concern. According to the observation of artificial spent nuclear fuel by a scanning electron microscope, fissiogenic Cs and Ba are known to migrate to grain boundaries, fractures and gap regions between the edge of the spent nuclear fuel pellet and the surrounding metal cladding and form oxide precipitates [21]. Although it has been shown that the fissiogenic ${ }^{135} \mathrm{Ba}$ and ${ }^{137} \mathrm{Ba}$ behaved as $\mathrm{C}$ s from the Ba isotopic studies of bulk analyses, there was no strong evidence for the enrichment of fissiogenic Cs [33,34]. Therefore, in situ isotopic analysis of $\mathrm{Ba}$ for the reactor materials is desirable to search for the hot spot of fissiogenic Cs. 
Conventional in situ isotopic analyses with SIMS cannot measure trace elements with high atomic number like Ba because of the existence of significantly large background and isobars derived possibly from unknown molecular compounds. Groopman et al. [6] used their ion probe facility, named the Naval Ultra Trace Isotopes Laboratory's Universal Spectrometer (NAUTILUS) consisting of a combination SIMS and single stage accelerator mass spectrometer, to enable in-situ and molecular-isobar-free isotopic analyses and perform the in situ Ba isotopic measurements. Then, they found the enrichments of ${ }^{135} \mathrm{Ba}$ and ${ }^{137} \mathrm{Ba}$ in a reactor sample collected from a drill hole S2 in the gallery SD37 at RZ13. As a result of the in situ Ba isotopic analysis, they found several hot spots of fissiogenic Ba. Interestingly, one of the hot spots of fissiogenic ${ }^{135} \mathrm{Ba}$ and ${ }^{137} \mathrm{Ba}$ coexisted with $\varepsilon$-particle. Their isotopic results show that most fissiogenic ${ }^{135} \mathrm{Ba}$ and ${ }^{137} \mathrm{Ba}$ migrated as $\mathrm{Cs}\left({ }^{135} \mathrm{Cs}\right.$ and ${ }^{137} \mathrm{Cs}$, respectively) within five years after the reactor shutdown.

\section{Application to Particle Physics}

The Oklo natural reactor may also provide a possibility of isotopic shifts in what was formerly thought to be fundamental physical constants related to particle physics. Thermal neutron capture cross section of ${ }^{149} \mathrm{Sm}$ is known to be dominated by extremely low resonance energy, $E_{r}$, of the neutron capture. The isotopic shifts of ${ }^{149} \mathrm{Sm}-{ }^{150} \mathrm{Sm}$ caused by neutron capture reaction in the Oklo RZs may put temporal constraints on the variability of coupling constants over 2 billion years, if the neutron capture resonance has moved by $0.01 \mathrm{eV}$ after the comparison of the data between the time at the Oklo RZs operating ( 2 billion years ago) and the present, $\Delta E_{r}=E_{r}(\mathrm{Oklo})-E_{r}$ (present). Regarding limits on the time variation of coupling constants from the isotopic data of the Oklo RZs, those on the variation of the neutron capture cross section act as constraints on the variation of the resonance energies of neutron capture from which we may put constraints on the time variation of particle coupling strengths.

In the physics research field, such quantities as the Planck's constant $\hbar$, the velocity of light $c$, the Newton's constant of gravitation $G$, the Coulomb coupling constant $\alpha=\mathrm{e}^{2} /(4 \pi c \hbar)$, and the strong-interaction counterpart of the fine-structure constant $\alpha_{\mathrm{s}}=\mathrm{g}^{2} /(4 \pi c \hbar)$ are believed to be the same at all places and times in the universe. They are called fundamental constants. Dirac (1937) firstly suggested that $G$ might vary as $t^{-1}$, over the cosmological time scale $t$, and proposed "Large-numbers Hypothesis [35]" showed the possibility of a time variation of one of the fundamental constants. In his theory, $\dot{G} / G \sim 10^{-10}$ year $^{-1}$ was speculated, where $\dot{G}=\Delta G / t$ [36].

Since then, "Large-numbers Hypothesis" has been proffered by some scientists as the result of a numerological coincidence. Several attempts have been examined to set experimental and observational constraints on the time variation of fundamental constants. Regarding $G$, the solar-system astrometric data from the Viking landers on Mars [37] showed that the most restrictive bound is an order of magnitude below Dirac's prediction. On the other hand, regarding the fine structure constants, $\alpha$ and $\alpha_{\mathrm{s}}$, several approaches have been examined, including the isotopic balance of ${ }^{187} \mathrm{Re}^{187}$ Os decay systematics in terrestrial materials [38], adsorption of quasar spectra by gas clouds from the observation using Very Large Telescope [39], and comparison of the frequencies of two optical atomic clocks between $\mathrm{Al}^{+}$and $\mathrm{Hg}^{+}$[40]. These results of the upper bounds for $\alpha$ and $\alpha_{\mathrm{s}}$ are small, but the estimate from the Sm isotopic data from the Oklo RZs [41,42] gives more critical time constraints than any other method. The results of time variations of the fine structure constant given by the representative approaches are listed in Table 2.

Table 2. Time variation of the fine structure constant $(\dot{\alpha} / \alpha)$ estimated from several methods.

\begin{tabular}{ccc}
\hline Method & $\dot{\alpha} / \alpha$ & References \\
\hline Half-life of ${ }^{187} \operatorname{Re}$ & $<3 \times 10^{-13}$ & {$[38]$} \\
QSO spectroscopy & $(6.40 \pm 1.35) \times 10^{-16}$ & {$[39]$} \\
Frequency of ion optical clocks & $(-1.6 \pm 2.3) \times 10^{-17}$ & {$[40]$} \\
Oklo phenomenon & $<1 \times 10^{-17}$ & {$[41,42]$} \\
\hline
\end{tabular}




\section{Summary}

This review covers in situ isotopic measurement capabilities of microbeam facilities, including SHRIMP. Isotopic studies provide useful information to estimate the reactor conditions and to understand the behavior of radionuclides in and around natural reactors. As conventional analytical techniques before 2000 were based on bulk analysis, the situation of heterogeneous distribution of fissiogenic products in and around natural reactors remained unclear. Since that time, the introduction of microbeam probes for the chemical and isotopic analysis represents a great advance toward understanding the migration and retardation of fissiogenic products into specific phases. Finding of several types of microminerals in and around the RZs led to further insights on the mechanism of geochemical behaviors of fission products from the application of in situ isotopic characterization.

In this review, the following topics were selected: (1) selective uptake of Ra deduced from $\mathrm{Pb}$ isotopic analyses in clay minerals, (2) chemical fractionation between $\mathrm{Pu}$ and $\mathrm{U}$ evaluated from the isotopic variations of ${ }^{235} \mathrm{U}$ in apatite, (3) evidence for the local occurrence of water radiolysis from the existence of minium $\left(\mathrm{Pb}_{3} \mathrm{O}_{4}\right)$ coexisted with galena $(\mathrm{PbS}),(4)$ formation mechanism of $\varepsilon$-particles under various redox conditions deduced from the isotopic variations of fissiogenic $\mathrm{Mo}, \mathrm{Zr}$, and $\mathrm{Ru}$, (5) retardation behavior of fissiogenic REE characterized from the isotopic variations of $\mathrm{Ce}, \mathrm{Nd}, \mathrm{Sm}$, and Eu in REE bearing minerals, (6) construction of the model for cycling operation of RZs supported from fissiogenic $X e$ isotopic data, and (7) finding of hot spots of fissiogenic ${ }^{135} \mathrm{Cs}$ and ${ }^{137} \mathrm{Cs}$, presently decayed to ${ }^{135} \mathrm{Ba}$ and ${ }^{137} \mathrm{Ba}$, respectively, resulted from the chemical fractionation between $\mathrm{Cs}$ and $\mathrm{Ba}$.

The aim of the isotopic studies for the Oklo and Bangombé natural reactors is mainly to support the assessment of nuclear waste management but also evaluation of the time variation of fundamental constants in the research field of particle physics.

Funding: This research received no external funding.

Acknowledgments: I am grateful to the Guest Editor Janusz Janeczek for providing me a chance to write this review.

Conflicts of Interest: The author declares no conflict of interest.

\section{References}

1. Horie, K.; Hidaka, H.; Gauthier-Lafaye, F. Isotopic evidence for trapped fissiogenic REE and nucleogenic $\mathrm{Pu}$ in apatite and $\mathrm{Pb}$ evolution at the Oklo natural reactor. Geochim. Cosmochim. Acta 2004, 68, 115-125. [CrossRef]

2. Kikuchi, M.; Hidaka, H.; Gauthier-Lafaye, F. Formation and geochemical significance of micro-metallic aggregates including fissiogenic platinum group elements in the Oklo natural reactor, Gabon. Geochim. Cosmochim. Acta 2010, 74, 4709-4722. [CrossRef]

3. Hidaka, H.; Horie, K.; Gauthier-Lafaye, F. Transport and selective uptake of radium into natural clay minerals. Earth Planet. Sci. Lett. 2007, 264, 167-176. [CrossRef]

4. Meshik, A.P.; Kehm, K.; Hohenberg, C.M. Anomalous xenon in zone 13 Okelobondo. Geochim. Cosmochim. Acta 2000, 64, 1651-1661. [CrossRef]

5. Meshik, A.P.; Hohenberg, C.M.; Pravdivtseva, O.V. Record of cycling operation of the natural nuclear reactor in the Oklo/Okelobondo area in Gabon. Phys. Rev. Lett. 2004, 93, 182302. [CrossRef]

6. Groopman, E.E.; Willingham, D.G.; Meshik, A.P.; Pravdivtseva, O.V. Discovery of fissiogenic Cs and Ba capture five years after Oklo reactor shutdown. Proc. Natl. Acad. Sci. USA 2018, 115, 8676-8681. [CrossRef]

7. Kikuchi, M.; Hidaka, H.; Horie, K.; Gauthier-Lafaye, F. Redistribution of REE, Pb and U by supergene weathering studied from in-situ isotopic analyses of the Bangombé natural reactor, Gabon. Geochim. Cosmochim. Acta 2007, 71, 4716-4726. [CrossRef]

8. Kikuchi, M.; Hidaka, H.; Horie, K. Geochemical behavior of radionuclides in highly altered zircon above the Bangombé natural fission reactor, Gabon. Phys. Chem. Earth 2008, 33, 978-982. [CrossRef]

9. Hidaka, H.; Jeneczek, J.; Skomurski, F.N.; Ewing, R.C.; Gauthier-Lafaye, F. Geochemical fixation of rare earth elements into secondary minerals from sandstones beneath a natural fission reactor at Bangombé, Gabon. Geochim. Cosmochim. Acta 2005, 69, 685-694. [CrossRef] 
10. Komarneni, S.; Kozai, N.; Paulus, W.J. Superselective clay for radium uptake. Nature 2001, 410, 771. [CrossRef]

11. Tachi, Y.; Shibutani, T.; Sato, M.; Yui, M. Experimental and modeling studies on sorption and diffusion of radium in bentonite. J. Contam. Hydrol. 2001, 47, 171-186. [CrossRef]

12. Grütter, B.L.; von Gunten, H.R.; Rössler, E. Sorption of barium on unconsolidated glaciofluvial deposits and clay minerals. Radiochim. Acta 1992, 58, 259-265. [CrossRef]

13. Zhang, P.-C.; Brady, P.V.; Arthur, S.E.; Zhou, W.-Q. Adsorption of barium(II) on montmorillonite: An EXAFS study. Colloids Surf. A Physicochem Eng. Asp. 2001, 190, 239-249. [CrossRef]

14. Bros, R.; Turpin, L.; Gauthier-Lafaye, F.; Holliger, P.; Stille, P. Occurrence of naturally enriched 235U: Implications for plutonium behaviour in natural environments. Geochim. Cosmochim. Acta 1993, 57, 1351-1356. [CrossRef]

15. Bros, R.; Carpena, J.; Sere, V.; Beltritti, A. Occurrence of Pu and fissiogenic REE in hydrothermal apatites from the fossil nuclear reactor 16 at Oklo (Gabon). Radiochim. Acta 1996, 74, 277-282. [CrossRef]

16. Naudet, R. Oklo: Des Réacteurs Nucléaires Fossils; Collection du Commissariat à l'Energie Atomique: Paris, France, 1991.

17. Lugmair, G.W.; Marti, K. Sm-Nd-Pu timepieces in the Angra dos Reis meteorite. Earth Planet. Sci. Lett. 1977, 35, 273-284. [CrossRef]

18. Chapman, N.A.; Smellie, J.A.T. Introduction and summary of the workshop, Natural analogues to the conditions around a final repository for high-level radioactive waste. Chem. Geol. 1986, 55, 167-173. [CrossRef]

19. Shoesmith, D.W. Fuel corrosion processes under waste disposal conditions. J. Nucl. Mat. 2000, $282,1-31$. [CrossRef]

20. Savary, V.; Pagel, M. The effects of water radiolysis on local redox conditions in the Oklo, Gabon, natural fission reactors 10 and 16. Geochim. Cosmochim. Acta 1997, 61, 4479-4494. [CrossRef]

21. Kleykamp, K. The chemical state of fission products in oxide fuels. J. Nucl. Mater. 1985, 131, 221-246. [CrossRef]

22. Thomas, L.E.; Guenther, R.J. Characterization of low-gas-release LWR fuels by transmission electron microscopy. In Scientific Basis for Nuclear Waste Management XII. (eds. W. Lutze and R. C. Ewing). Mater. Res. Soc. Symp. Proc. 1989, 127, 293. [CrossRef]

23. Cui, D.; Low, J.; Sjöstedt, C.J.; Spahiu, K. On Mo-Ru-Tc-Pd-Rh-Te alloy particles extracted from spent fuel and their leaching behavior under $\mathrm{Ar}$ and $\mathrm{H}_{2}$ atmosphere. Radiochim. Acta 2004, 92, 551-555. [CrossRef]

24. Gauthier-Lafaye, F.; Holliger, P.; Blanc, P.L. Natural fission reactors in the Franceville basin, Gabon: A review of the conditions and results of a "critical event" in a geological system. Geochim. Cosmochim. Acta 1996, 60, 4831-4852. [CrossRef]

25. Hidaka, H.; Shinotsuka, K.; Holliger, P. Geochemical behaviour of ${ }^{99}$ Tc in the Oklo natural fission reactors. Radiochim. Acta 1993, 63, 19-22. [CrossRef]

26. Hidaka, H.; Holliger, P.; Gauthier-Lafaye, F. Tc/Ru fractionation in the Oklo and Bangombé natural fission reactors, Gabon. Chem. Geol. 1999, 155, 323-333. [CrossRef]

27. Utsunomiya, S.; Ewing, R.C. The fate of the epsilon phase (Mo-Ru-Pd-Tc-Rh) in the $\mathrm{UO}_{2}$ of the Oklo natural fission reactors. Radiochim. Acta 2006, 94, 749-753. [CrossRef]

28. Janeczek, J. Mineralogy and geochemistry of natural fission reactors in Gabon. Rev. Mineral. 1999, 38, 321-392.

29. Mathieu, M.; Zetterstrom, L.; Cuney, M.; Gauthier-Lafaye, F.; Hidaka, H. Alteration of monazite and zircon and lead migration as geochemical traces of fluid paleocirculations around the Oklo-Okelobondo and Bangombé natural nuclear reaction zones (Franceville basin, Gabon). Chem. Geol. 2001, 171, 147-171. [CrossRef]

30. Evans, L.Z.; Jensen, K.A.; Ewing, R.C. Uraninite recrystallization and Pb loss in the Oklo and Bangombé natural fission reactors, Gabon. Geochim. Cosmochim. Acta 2004, 69, 1589-1606. [CrossRef]

31. Dymkov, Y.; Holliger, P.; Pagel, M.; Gorshkov, A.; Artyukhina, A. Characterization of a La-Ce-Sr-Ca aluminous hydroxy phosphate in nuclear zone 13 in the Oklo uranium deposit (Gabon). Miner. Depos. 1997, 32, 617-620. [CrossRef]

32. Brookins, D.G.; Lee, M.J.; Mukhopadhyay, B.; Bolivar, S.L. Search for fission-produced Rb, Sr, Cs and Ba at Oklo. Proc. Oklo Phenom. 1975, 401-413. 
33. Hidaka, H.; Holliger, P.; Masuda, A. Evidence of fissiogenic Cs estimated from Ba isotopic deviations in an Oklo natural reactor zone. Earth Planet. Sci. Lett. 1993, 114, 391-396. [CrossRef]

34. Hidaka, H.; Gauthier-Lafaye, F. Ba isotopic signature for early differentiation between Cs and Ba in natural fission reactors. Geochim. Cosmochim. Acta 2008, 72, 4123-4135. [CrossRef]

35. Dirac, P.A.M. The cosmological constants. Nature 1937, 139, 323. [CrossRef]

36. DeLaeter, J.R.; Hidaka, H. The role of mass spectrometry in the Oklo-Bangombé natural reactors. Mass Spectrom. Rev. 2007, 26, 683-712. [CrossRef] [PubMed]

37. Hellings, R.W.; Adams, P.J.; Anderson, J.D.; Keesey, M.S.; Lau, E.L.; Standish, E.M.; Canuto, V.M.; Goldman, I. Experimental test of the variability of G using Viking lander ranging data. Phys. Rev. Lett. 1983, 51, 1609-1612. [CrossRef]

38. Dyson, F.J. Time variation of the charge of the proton. Phys. Rev. Lett. 1967, 19, 1291-1293. [CrossRef]

39. Webb, J.K.; King, J.A.; Murphy, M.T.; Flambaum, V.V.; Carswell, R.F.; Bainbridge, B.M. Indications of a spatial variation of the fine structure constant. Phys. Rev. Lett. 2011, 107, 191101. [CrossRef] [PubMed]

40. Rosenband, T.; Hume, D.B.; Schmidt, P.O.; Chou, C.W.; Brusch, A.; Lorini, L.; Oskay, W.H.; Drullinger, R.E.; Fortier, T.M.; Stalnaker, J.E.; et al. Frequency ratio of $\mathrm{Al}+$ and $\mathrm{Hg}+$ single-ion optical clocks: Metrology at the 17th decimal place. Science 2008, 319, 1808-1812. [CrossRef]

41. Shlyakhter, A.I. Direct test of the constancy of fundamental nuclear constants. Nature 1976, $264,340$. [CrossRef]

42. Fujii, Y.; Iwamoto, A.; Fukahori, T.; Ohnuki, T.; Nakagawa, M.; Hidaka, H.; Oura, Y.; Möller, P. The nuclear interaction at Oklo 2 billion years ago. Nucl. Phys. B 2000, 573, 377-401. [CrossRef]

Publisher's Note: MDPI stays neutral with regard to jurisdictional claims in published maps and institutional affiliations. 